\title{
The Impacts of Genetic Counseling on The Quality of Children
}

\author{
by \\ SJARIF HIDAJAT EFFENDI \\ (From the Department of pediatrics, Padjajaran University, \\ Bandung)
}

\section{Introduction}

The succes of our National Family Planning Program and awareness of people to the motto of: "The norm of a small, hapy and prosperous family" has led our people, especially the eligable couples, to think no more about quantity, but the quality of their children. There is a tendency that they do need assurance of completely healty children, the present or the coming ones. This fact leads our Healt Service Personnel to the awareness that they must be able to solve people's problems related to their desire for good quality children.

Increasing the children's quality of life greatly depens on the efforts within the following stages of their lives: conception, pregnancy, delivery and neonatal conditions. It means that marriage/ genetic counseling, antenatal care, and perinatal services play a very important role. Every disturbance within these periods will lead to serious damage to the growth and development of organs, especially the brain. This condition might result in handicapped and malformed children.

As infectious disease are brought under control and decreasing, the relative importance of overcoming disorders that are wholy or partly genetic has been a decrease in the perinatal.Mortality rate, insidence of infections and malnutritions in hospitals in Indonesia, but cases of congenital hereditary disorders are increase.

Every year thousands of familiels are effected by the birth of an abnormal child. About $0,5 \%$ of newborns have chromosom abnormality with moderate to severe phenotypic effects.

Presented at the IVth International Congress for Maternal \& Neonatal Health; IVth National Congress of The Indonesian Association for Perinatology, Bandung, Sept. 11-14, 1991.

Received : October 14, 1991 
Another 0,5 - $1 \%$ suffer from the consequences of single-gene defects (dominant, recessive, or $\mathrm{x}$-linked), and about $2 \%$ have malformation that may in part be due to inheritable factors. Altogether, about $4 \%$ of new borns have a serious defect that is recognized at birth aor within their first year. It has been estimated that bout a third of all children in pediatric hospitals are being treated for conditions that have genetic component. Thus there can be no doubt about the need for increased genetic information and counseling many families requiring it.

In countries with low ifant mortality rates the cause of death are mostly perinatal problems and congenital disorders. That is why the high incidence of the disease during the perinatal period and the high neonatal and perinatal death rates make it important to identify the fetus and infant risk as early as possible.

Causes of congenital malformation are genetic and non genetic factors. The non-genetic factors are such as uterine abnormalities, teratogens, and poor maternal conditions.

This paper discusses some aspects of genetic counseling including its process, organization, goal, and its role in Promoting the quality of children.

\section{Congenital Genetic Abnormality}

About $3 \%$ children in developed contries are mentally retarded. The ratio of male and female is about 1.5-2:1. About one fifth of those mentally retarded children have a ahromosomal basis for developmental retadations.

A useful classification of deseases having a genetic background would be :

1. Single mutant gene (mendelian) disorders

2. Chromosomal abberation syindromes
3. Deseases determined by multifactorial inheritance-genetic predispotion with environmental interaction

4. Somatic cell genetic diseases (neoplasia, aging, autoimmune disease, some congenital malformations)

At this time there are about 4300 diseases having a genetic basic. It is increasing dramatically i.e : 1500 in 1986, 2800 in 1978, 3300, in 1983, and 3900 in 1986.

\section{Genetic Counseling}

Genetic counseling is the process by which patients or relatives at risk of a disorder that may be hereditary are advised of the consequences of the disorders, the probability of developing and transmiting it anf of the ways in which this may be prevented or ameliorated.

Based on this definition there are 3 aspects of genetic counseling :

1. The diagnostic aspect without which all advice will be baseless and presumptious. There is no alternative to exact diagnosis. To ases genetic risk one needs a precise, accurate, and detailed family history apart from the diagnosis;

2. The actual estimation of risks which may be simple in some situations and complex in others;

3. A supportive role, ensuring that the consultee actually benefits from the advice given and from the various preventive measures that may be available. 
Figure 1. Map of the genetic counseling process

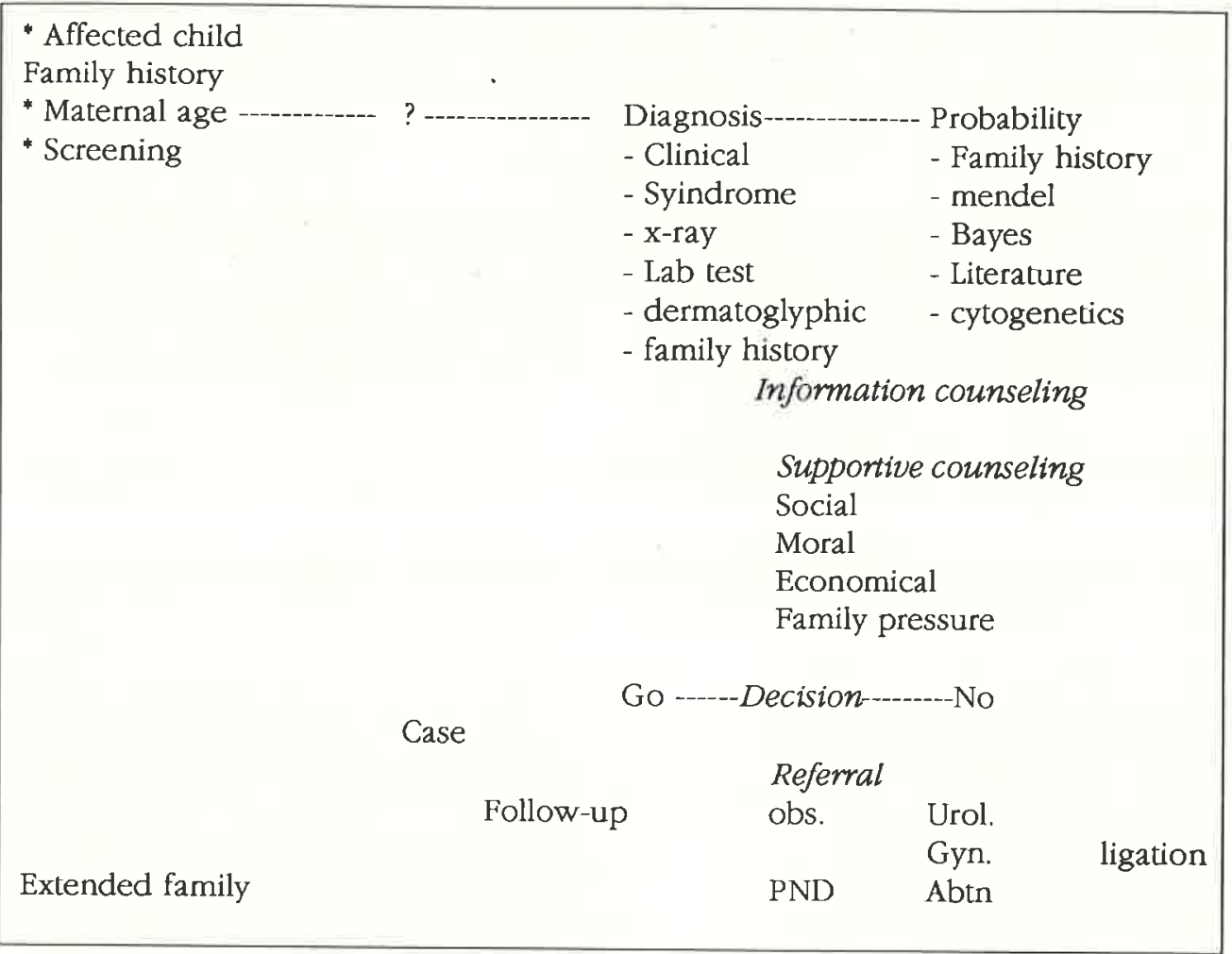

The aim of genetic counseling is to convey medical and genetic facts to the affected or potentially affected family and to explain the options available. However, it involves much more than simply reeling off statements of probability

Figure 1. Depicts the stages of genetic counseling process.

It begins with a questions raised by the advent of a child with the possibility of a genetic disorders, other aspectrs of the family history, etc. There must be a diagnosis which may depend on information from clinicians, syndromologist, X-ray studies, laboratory test, dermatoglyphics, cytogenetics and the family history. 'To answer the question usually requires estimat- ing probability using information from the family history, cytogenetics, the liturature, the mendelian principles and Bayesia calculations. Following informative and supportive counseling (often influenced by social, moral, economic, and family pressure) the counselee may reach a decision either to refrain from reproduction or to go ahead. Either of these may require appropriate referral. If the "Go" decision results in a recurrence, further counseling may be required. Follow-up of the counselee and the extended family may result in reentry into the process.

From the facts mentioned above, it appears that the corner-stone of genetic counseling is a correct diagnosis. This 
precise and accurate diagnosis can only be obtained-by establishing a good, professional and multidisciplinary cooperation among the pediatricians, obstetri-

cians, syndromologists, molecular biologists, biochemists, cytogenetists, radiologists, neurologists, cardiologists, social workers, psychiatrists, and so on.

\section{Organization}

The activities of genetic counseling should be well organized together with other disciplines supporting Clinical Ge netics as in the following example :

A fact is that it is not possible to set up a genetic clinic as an individual, as cooperation of multydisciplinary examinations is an absolute requirement.

Figure 2. The Organization of Clinical Genetics

\begin{tabular}{|c|c|c|c|c|c|c|c|}
\hline \multicolumn{8}{|c|}{ 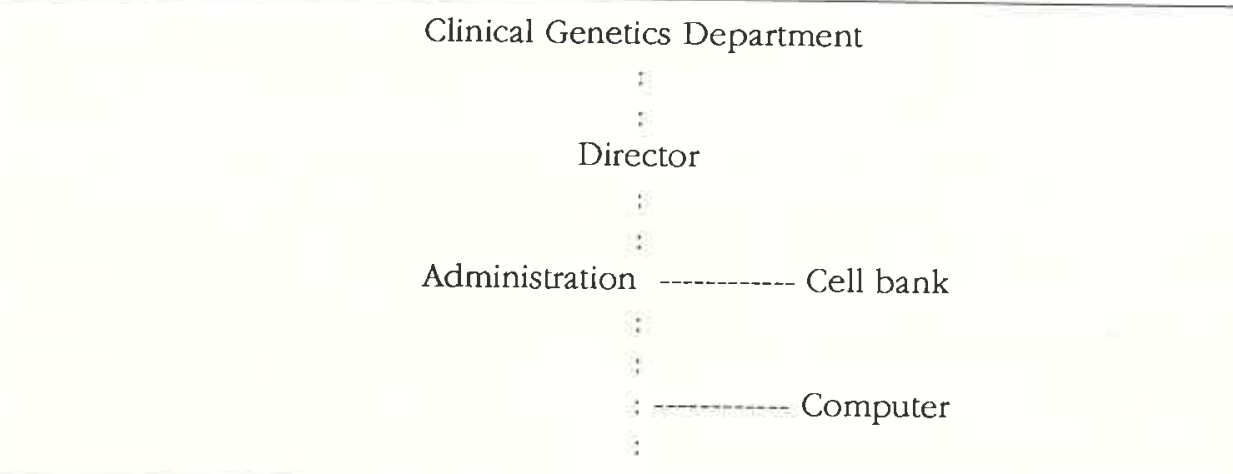 } \\
\hline $\begin{array}{l}: \\
: \\
\text { Meta- } \\
\text { bolic } \\
\text { dis- } \\
\text { order } \\
: \\
:\end{array}$ & $\begin{array}{l}: \\
: \\
\text { Meta- } \\
\text { bolic } \\
\text { lab } \\
: \\
: \\
:\end{array}$ & $\begin{array}{l}: \\
: \\
\text { Enzym- } \\
\text { ology } \\
\text { pre- } \\
\text { and } \\
\text { post- } \\
\text { natal }\end{array}$ & $\begin{array}{l}: \\
: \\
\text { DNA } \\
\text { lab } \\
: \\
: \\
: \\
:\end{array}$ & $\begin{array}{l}: \\
\text { Bio } \\
\text { che- } \\
\text { mic } \\
\text { lab } \\
: \\
:\end{array}$ & $\begin{array}{l}: \\
: \\
\text { Chromo- } \\
\text { some } \\
\text { lab } \\
: \\
: \\
:\end{array}$ & $\begin{array}{l}: \\
: \\
\vdots \\
: \\
: \\
: \\
: \\
:\end{array}$ & $\begin{array}{l}: \\
: \\
\vdots \\
\vdots \\
: \\
\vdots \\
\vdots \\
\vdots\end{array}$ \\
\hline $\begin{array}{l}\text { Depar } \\
\text { pediat }\end{array}$ & ent of & $\begin{array}{l}\text { Departm } \\
\text { gy and C }\end{array}$ & $\begin{array}{l}\text { nt of Ce } \\
\text { enetics }\end{array}$ & biolo- & & $\begin{array}{l}\text { Genetic } \\
\text { Counsel- } \\
\text { ing }\end{array}$ & $\begin{array}{l}\text { Department } \\
\text { of ob.Gyn }\end{array}$ \\
\hline
\end{tabular}

\section{Prenatal Diagnosis}

The goal of genetic counseling in relation to ensure the quality of children is the action of prevention, wether it is done by prenatal diagnostics or calculating the recurrence risk.

It is becoming increasingly possible to evaluate the developing fetus in an attempt to detect serious disorders early enough to allow for termination of affected pregnancies when there is significant risk often a recurrance risk of serious disorder.

The criteria for prenatal diagnosis are as follows :

1. Disorders sufficiently severe to warrant termination of pregnancy

2. 'Treatment absent or unsatisfactory

3. Termination of pregnancy acceptable to the couple concerned

4. Accurate prenatal diagnostic test available

5. Genetic risk to pregnancy sufficiently high

\section{The Role of Genetic Counseling in Promoting the Quality of Children}

The impact of a diagnosis on the consultee can cause a variety of reactions. they include anger, gult, shame and blame casting. The first stage of shock and disorganisation is soon taken over by the second stage of rationalization, denial and blame casting. Finally when they reach the third stage of equalization, they are able to act more relistic and function more effective.

One's perception of risk and willingness to accept it are higly subjective matters, depending on one's personality, experiences, moral convictions, and especially on the burden of care imposed by the condition in question.

When the genetic prognosis is unfa-

vorable, a couple may consider only two options for further action : to refrain from childdbearing or to risk a defective birth. If abortain is an acceptable alternative, however, prenatal diagnosis followed by possible termination of pregnancy is now available in a growing number of cases. Alternatively, a couple may choose adoption or an appropriate reproductive technology using either a donor egg or donor sperm.

When this procedure of genetic counseling is completely done, it means that we can as maximal as possible eliminate the birth of congenital genetic malformed neonates.

\section{Conclusions and Suggestions}

As perinatal problems are brought under control, the relative importence of overcoming genetic disorders has been steadly increasing.

Genetic counseling (a tool to solve those genetic problems) can ensure to eliminate or prevent genetic disorders, supporting good quality children to mankind. But to set up a genetic counseling activity a good multidisciplinary cooperation and collaboration is needed.

The activity of genetic counseling, however, needs and accurate diagnosis as a cornerstone.

To face these coming problems, cadresation of young basic scientists should be started from now on. Especially for Indonesia, the question arises whether the curriculum of the medical Faculty which is at present for a great part based on community oriented medicine, should be changed gradually towards a more basic science program such as biochemis 


\section{REFERENCES}

1. Nora JJ, Fraser FC. Medical genetics, principles and practice, 3rd ed, Philadelphia, London: Lea \& Febiger, 1989.

2. Mange AP, Mange EJ. Genetics : Human aspects, 2nd Ed. Massachusetts Sinauer Associates, Inc. Publishers Sunderland.

3. Wahidiyat I, Boedjang RF. The role of perinatology in tha improvement of the quality of mankind. Perinatology; Proceedings of the 5th Asia-Oceania Congress of perinatology, Bali, Indonesia, 1988. Excerpta Medica, Amsterdam-New York-Oxford.

4. Jones KL, in: Smith's Recognizable patterns of human malformation, 4th Ed. W.B.
Saunders Co. 1988.

5. Harper PS. Pratical genetic counseling, 2nd. Wright, Bristol, 1984.

6. Jarenverslag, Stichting Klinische Genetica Regio, Rotterdam, 1984-1987.

7. Mc Kusick VA. Mendelian inheritance in man. Catalogs of autosomal recessive, and $\mathrm{x}$-linked phenotypes. Eighth Ed. Baltimore and London: The John Hopkins University press, 1988.

8. Tijdink GAJS, Curfs LMG, Frijns JP. Cytogenetic causes of mental retardation. A multidisciplinary approach in "De Hondsberg", 1988. 